\title{
The Breakdown of State-building: From the Nation to Radicalisation
}

\author{
The Security Aspects of Exclusion and Identity Formation
}

\author{
Peter Knoope \\ Senior Visiting Fellow Clingendael Research \\ pknoope@clingendael.nl
}

\author{
Saré Knoope \\ Independent Researcher \\ sareknoope@hotmail.com
}

\begin{abstract}
This article attempts to explore the nexus between exclusionary state-building practices, inter-ethnic relations and Violent Extremism and Radicalisation that Lead to Terrorism (VERLT). The current focus on individual trajectories has left the social context in which individuals radicalise underexplored. By taking a birds-eye view, this article aims to untangle the ways in which particular historic conditions and perceptions of discrimination and marginalisation following state-building practices feed specifically into the radicalisation of minority communities. Following a comparison between state-building practices in Turkey, China and Spain and the impact on Kurdish, Uyghur and Basque identity construction respectively, the authors argue that the failure to include minority groups into the identity of the state is one of the key reasons for the politicisation of minority identities. This implies the need for inclusionary policies as a response to VERLT. It is exactly through the promotion, facilitation and execution of inclusive policies that the OSCE can make an important contribution.
\end{abstract}

\section{Keywords}

state building - minorities - radicalisation - identity construction - marginalisation VERTL - exclusionary practices - Uyghurs - Kurds - Basques 


\section{Introduction}

It is generally assumed that 'exclusion' is a major factor in radicalisation. ${ }^{1}$ The theoretical underpinning of this assumption is, however, still underexplored. Where scholars have pointed to the structural link between modern statebuilding and exclusion ${ }^{2}$ the link between identity formation and the creation of the out-group; the question as to when exclusion and identity formation lead to violent opposition continues to puzzle many. Mostly because they tend to study specific individual cases. This is a case of 'overlooking the forest because the trees get in the way'. Where for each individual there might be a unique pathway, there is a broader pattern that deserves, if not demands our attention. Radicalisation is not simply an individual trajectory. It is not simply about the trees. It is about the forest. The current dominant discourse has, however, cast a shadow on the social context in which individuals radicalise. The argument of this essay is grounded in the logic of the forest, as we aim to explore the nexus between state-building, inter-ethnic relations and vulnerability to recruitment by brokers of violence, i.e. actors that effectively translate feelings of anger and despair into violent behavior. This leaves us to conclude that statebuilding has contributed, and will continue to contribute, to radicalisation and recruitment processes all throughout the world. This shift in focus from the individual to the collective involves a comprehensive approach to countering Violent Extremism and Radicalisation that Lead to Terrorism (VERLT) whereby long-term structural issues take a prominent stage. An area in which the OSCE is well-suited given its commitment to, and role in preventing and resolving conflicts, promoting human rights, and safeguarding the rights of national minorities. ${ }^{3}$ This requires a thorough and well-grounded understanding of

1 For example Peter R. Neumann, "Countering Violent Extremism and Radicalisation that Lead to Terrorism: Ideas, Recommendations, and Good Practices from the oscE Region" 28 September 2017; United Nations Development Programme, "Preventing Violent Extremism Through Promoting Inclusive Development, Tolerant and Respect for Diversity," UNDP, 2016; RAN Centre of Excellence. "The Root Causes of Violent Extremism," RAN Issue Paper, January, 2016; Exclusion also features prominently among the range of motivations for EU citizens to join extremist group, see International Centre for Counter Terrorism, "The Foreign Fighters Phenomenon in the European Union, Profiles, Threats and Policies," Icct April 2016.

2 Hannah Arendt, The Origins of Totalitarianism (Orlando: Houghton Mifflin Harcourt, 1973); Agamben, G. 1998. Homo Sacer. Sovereign Power and Bare Life. Stanford, CA: Stanford University Press; Andreas Wimmer, Nationalist Exclusion and Ethnic Conflict: Shadows of Modernity. (Cambridge: Cambridge University Press, 2002).

3 Neumann, "Countering Violent". 
the dynamics of violent extremism. This paper aims to grasp these dynamics by specifically exploring the ways in which particular historic conditions and perceptions of discrimination and marginalisation following nationalist exclusion $^{4}$ feed specifically into the radicalisation of minority communities. The following paragraph lays out our line of reasoning. The 'steps' from state-building to radicalisation will be untangled in more detail in the subsequent chapter, after which three cases will be explored with the aim of evaluating the practical significance of the theoretical framework provided.

We believe that the contemporary phenomenon of minority exclusion started with the rise of the nation-state as the dominant model of political organisation, as it has generated the need for the state to construct and actively promote the idea of a unified political community (i.e. nationalism) in order to gain and retain legitimacy. ${ }^{5}$ Because the state is constructing and actively promoting this idea of unity, its survival depends on the assimilation, if not suppression and exclusion of those that do not conform to the national identity of the state. The policies available to, and enacted by governments are varied, ranging from assimilation and integration to denial of differences and active suppression. Sometimes various policies are combined. Yet, as will become clear, those that fail to take on the identity of the state (which often overlaps with the identity of the majority) are most commonly depicted as the threatening 'other'. It is argued that groups define themselves merely in relation to the other. ${ }^{6}$ Similarly to identity-construction processes, the state will actively seek the construction of a threatening 'other' in order to define a 'united' self. Yet, where the 'us' is forged, its flipside is found in the politicisation of the 'them'.

As will become clear from the three cases analysed, the failure to include minority groups into the identity of the state is one of the key reasons for the politicisation of minority identities as it works to strengthen communal bonds and fuel constructed 'nationalist' sentiments amongst minority groups. Identities grow particularly salient when they are perceived to be under threat, often following a process of securitisation. Consequently, as we aim to show, those that feel excluded, become more vulnerable to radicalisation and recruitment,

4 By nationalist exclusion we mean real or perceived policies of exclusion following nationstate building practices.

5 Elie Kedourie, Nationalism, Fourth expanded edition (Oxford, UK and Cambridge, MA: WileyBlackwell, 1993).

6 Frederik Barth, Ethnic Groups and Boundaries: the Social Organization of Cultural Difference (Long Grove, IL: Waveland Press, 1998). 
as recruiters exploit feelings of marginalisation and exclusion by offering a place of belonging; a new in-group; a 'nation' so to say. The discourse of injustice develops along national and ethnic lines, resulting in new, exclusive discourses that, as we have seen, can take on extremely violent forms. The most challenging is the final 'step' from anger to violence. As aforementioned, this sequence of reasoning has been obscured by the fact that the study of radicalisation has had a focus on individual cases and on 'talking to terrorists.' 7 This article seeks to address this void as it discloses the collective identity element in radicalisation that, as we will show, bears a lot of relevance.

The steps outlined above will also be explored by making use of three (present-day) examples that underscore the nexus between inter-ethnic relations and VERLT. These examples include the development of radical trends ${ }^{8}$ in the Kurdish population in Turkey, the radicalisation of Uyghurs in relation to ethnic exclusion in China and ethnicity issues and the development of violent movements (ETA) in Spain. The following section will disentangle our line of reasoning by providing the theoretical underpinning of our argument that links state-building practices to violent Extremism and Radicalisation that Lead to Terrorism. We will conclude by arguing that the unique mandate and position of the OSCE, and more specifically the HCNM, allows them to alert and advise governments on the consequences of exclusionary tendencies of state-building practices, while opening the way for dialogue between governments and minorities.

\section{State-building and Nationalism as the Drivers of Ethnic Exclusion}

Whereas scholars of nationalism provide conflicting answers to the question as to whether nationalism preceded the nation-state or the other way around, ${ }^{9}$ nation-states are rarely ever completely uniform, particularly but not exclusively when speaking of the so-called (post-) colonial state. In fact, following the rise of the nation-state as the dominant model of political organisation, the nation-state became the model to be pursued irrespective of the reality

7 The tendency to seek answers from an individual point of view.

8 In practice, the label used, i.e. whether a particular group is referred to as radicals, or separatists or terrorists, serves a particular purpose. Both governments and minority groups use particular wording and framing to legitimise their actions.

9 Modernist theorists including Hobsbawm and Gellner emphasise the novelty of both nations and nationalism whereby nationalism serves as the basis for newly established nations. Critics of modernist theories, including primordialists, perennialists and ethno-symbolists, though all to a varying degree, argue that nations are historically embedded. For more information see Anthony Smith, Ethno-symbolism and nationalism: A cultural approach (Abingdon: Routledge, 2009). 
on the ground..$^{10}$ Indeed, the nation-state proved an attractive alternative to multi-ethnic empires because of its potential to mobilise people. Yet, where the model seemed effectively tailored to the demands of its developers, the exact same model was to be exported to parts of the world where it proved only partially adequate to local circumstances. ${ }^{11}$ Effective control over territory and population required the distortion of this unfavourable reality in favour of nation-building processes. Consequently, in case of absence of favourable conditions, a homogenous nation and/or a unified political community had to be created one way or the other.

As argued by Patrick Hayden, the enforcement of national identity boundaries, eloquently put by Agamben as "the power to include by exclusion and exclude by inclusion", ${ }^{12}$ has become the core function of sovereign power. ${ }^{13}$ Where the nation-state system as the prime organising principle of international politics rests on the notion of - externally derived - sovereignty, a regime's legality does not safeguard legitimacy. After all, legitimacy is derived from below, i.e. 'the people.'14 As Cobban put it, "the divine right of the King was replaced with the divine right of the people."15 Nevertheless legitimacy is not necessarily derived from all the people. It is, however, the defining nature of nation-states to sell it as such, whereby the state serves as the embodiment of the nation, and the president or the king as the protector of the popular will. As argued by Anthony Smith, "we see that all nations are permeated, in varying degrees, by both civic and ethnic features and criteria." ${ }^{16}$ Whereas nationalism is aimed at creating a commonality between 'nationals', this commonality is rather forged than organically developed. In fact, policies of inclusion and the accommodation of differences are considered quite costly. On the other end of the spectrum, ethnic affiliation is most likely to generate loyalty, since it caters to compelling myths about kinship, cohesion and continuity. In addition, the

\footnotetext{
10 Andreas Wimmer, Nationalist Exclusion and Ethnic Conflict: Shadows of Modernity. (Cambridge: Cambridge University Press, 2002), 79 .

11 Kees van der Pijl, “Arab Revolts and Nation-State Crisis," New Left Review 70 (2011).

12 As cited in Barzoo Eliassi, "Statelessness in a world of nation-states: the cases of Kurdish diasporas in Sweden and the U K," Journal of Ethnic and Migration Studies 42, no.9 (2016): 1407.

13 Patrick Hayden, "From Exclusion to Containment: Arendt, Sovereign Power, and Statelessness," Societies Without Borders 3 (2008): 263 .

14 Max Weber, "Politics as a Vocation," in From Max Weber: Essays in Sociology, ed. and trans. H.H. Gerth and C. Wright Mills (New York: Oxford University Press, 1946).

15 Alfred Cobban, National Self-Determination (London: Oxford University Press, 1944).

16 In Anthony Smith, "Theories of Nationalism: Alternative Models of nation-Formation," in Asian Nationalism, ed. Michael Leifer (Abingdon: Routledge, 2002), 16.
} 
emphasis on democratic values like 'popular representation' downplayed the need to create inclusive forms of nationalism as a basis for national identity formation. Even - or maybe a simple 'also' suffices - 'democratic states' ${ }^{17}$ have failed to create an overarching, transcending form of citizenship due to the centrality of ethnic and religious identities to the notion of citizenship. Among others, Isin and Wood question the ability of citizenship to create a master political identity, as they argue identities are affirmed through citizenship, rather than broken down..$^{18}$ Minority groups are often disregarded, "since they do not belong to the nation in whose name the state has now to act."19 As a result, the narrowly defined identity of the state oftentimes excludes significant segments of society, ${ }^{20}$ whose identity is not merely underrepresented, but actively suppressed.

The exclusive nature of state- and nation-building processes thus follows from the need for "an imaginary domestic political community or nation that appears as unified and harmonious." ${ }^{21}$ As we have seen, 'ethnicity' provides a basis for the creation of this unified community. This inescapably produces a series of distinctions and division. But, there is more to it. As argued by Frederik Barth, ethnic groups define themselves merely in relation to the 'other'. As such, identities are not simply dependent on the existence of an in-group, but rather defined by their differences with the out-group. ${ }^{22}$ Where some seek to untangle the very essence of ethnicity and identity, or as Anthony D. Smith calls it, the 'cultural stuff', others, including John Armstrong, argue that identity is merely defined by how it is set apart from other identities. ${ }^{23}$ Borrowing from Frederik Barth, John Armstrong points to the existence of identities merely due to perceptions of group differences. ${ }^{24}$ Insiders exist only as a consequence of the presence of outsiders. It is interesting to consider this process of 'othering' as it is often referred to, in light of state-building practices. Following the state's quest for legitimacy, states seek the construction of a threatening

17 Democracy should be understood as a process, rather than a state of being.

18 Engin F. Isin and Patricia K. Wood, Citizenship and Identity (London: Sage, 1999).

19 Wimmer, Nationalist Exclusion, 92.

20 This may even be a majority as we have seen in a relevant number of cases.

21 Benedict Anderson, Imagined Communities: Reflections on the Origin and Spread of $\mathrm{Na}$ tionalism (London, New York: Verso, 2006; John M. Hobson, The State and International Relations (Cambridge: Cambridge University Press, 2000): 159 .

22 Anthony D. Smith, "Nations before nationalism? Myth and symbolism in John Armstrong's perspective," Nations and Nationalism 21 (2015): 165.

23 Anthony D. Smith, "Nations before nationalism? Myth and symbolism in John Armstrong's perspective," Nations and Nationalism 21 (2015): 165 .

24 Smith, "Nations before, 165. 
'other' in order to define a united 'self'. 25 As a consequence, narrowly defined identities are not solely an unforeseen result of state-building processes, but rather, or at least also, an explicit, and calculated outcome in the quest for unity and stability. In fact, the 'us vs. them' divide is not a mere by-product of the modern nation-state, but lays at its very foundation. Internal borders are a product of state building as much as external borders are. An 'internal other' as Hobson defines it, should therefore be understood as an inescapable reality of the modern nation-state, actively created and maintained. ${ }^{26}$ To make matters worse, competing forms of nationalism constitute another defining feature of the modern nation-state. In line with Foucault's line of reasoning that resistance will never fully escape the thing it resists against; ${ }^{27}$ the alienation of minorities from the state only further enhances the politicisation of ethnicity as the basis of identity. Consequently, the exclusive nature of state nationalism fosters the creation of exclusive nationalist sentiments amongst minorities, as identities grow salient when they are perceived to be under threat. Whereas individuals have multiple identities, the defining identity, i.e. the identity we associate with at a certain point in time, can differ from time and place, and can also be triggered by events and actors. Taking identities to be relational and reactive, exclusive forms of nationalism can be generated (oftentimes led by a charismatic figures) following repressive features of state nationalism. An upward spiral is set in motion whereby the creation of the (much needed) frightening 'other' is succeeded by resistance based on collective, yet exclusive identity formation on the part of the 'other'.

Traditionally, states are defined by their monopoly on violence. Yet, systematic, and excessive application of violence by the state against its own people de-legitimises the state in the eyes of its citizens. ${ }^{28}$ What follows is the breakdown of the social contract, whereby non-state actors hijack the state's monopoly on violence. It is our belief that processes of state-building leading to exclusion devaluate the social contract, including the notion of citizenship. As Hannah Arendt so aptly tried to lay bare in the Origins of Totalitarianism, formal citizenship can fail to ascertain rights and freedoms when policies of

\footnotetext{
25 Abbas Vali, "The Kurds and their "Others": Fragmented Identity and Fragmented Politics," Comparative Studies of South Asia, Africa and the Middle East XVIII, no. II (1998): 84-5; Hobson, The State, 159 .

26 Hobson, The State, 159.

27 Michel Foucault, "The Will to Knowledge," in The History of Sexuality: Volume One, trans. R. Hurley (London: Penguin Books, 1998), 95-6.

28 Michael Hardt and Antonio Negri, Multitude (New York: the Penguin Press, 2004): 14,21.
} 
exclusion serve to undermine it. ${ }^{29}$ Citizenship is practically eroded from its theoretical significance. People feel de facto stateless, meaning the nationality label obtained has no practical meaning. ${ }^{30}$ The international state-system has, however, ascertained that obtaining a state is the only viable option for those seeking to give practical meaning to their citizenship. Nevertheless, further disintegration of states is anxiously prevented, to say the least. ${ }^{31}$ What we are left with are minorities seeking to let their voices be heard in whatever way they deem possible, including through violent means. As mentioned, this can range from regional autonomy to the desire for secession; the other side however, might frame it as extremism or terrorism. As known, there is no international agreed definition of terrorism at the UN level, also because there is no agreement on whether a state can be considered a terrorist organisation, and secondly whether societal actors are ever entitled to violently oppose a repressive regime. ${ }^{32}$ In practice, however, the claim that violence is the language in which the state talks to us, justifies the choice to talk back in the same vocabulary. This is often used as the rationalisation for the use of violence. It is both the denial of the legitimacy of a supposed right to the monopoly on the use of certain hard security measures as well as the adaptation to the language encountered.

\section{The Politicisation of the Kurdish, Uyghur and Basque Identity}

The Kurds, Uyghurs and Basque together present, in our view, a complementary picture given there are significant differences in terms of geographical location, the role played by ideology and religion, as well as the timeframe within which the process unravelled. That makes it all the more interesting to find that, when comparing the state-building practices in each of the countries, the trajectories appear very similar. It shows how the international state-system has created minorities throughout the world, as minorities only exist in relation to majorities. It highlights how it has ascertained boundary construction

29 Arendt, The origins.

30 Latif Tas, "How international law impacts on statelessness and citizenship: the case of Kurdish nationalism, conflict and peace" International Journal of Law in Context 12, no.1 (2016): 47 .

31 As cited in Maria Montserrat Guibernau, Nations Without States: Political Communities in a Global Age (Cambridge: Polity Press, 1999), 27.

32 Ales Schmid, "Terrorism - The Definitional Problem" Case Western Reserve Journal of International Law 36, no. 2 (2004). 
following the state's quest for legitimacy. And lastly, it sheds light on the rather destructive repercussions of this state identity-construction. To this very day, the Kurdish case as well as the conflict in Spain directly impact OSCE participating states. Furthermore, the case of the Uyghurs indirectly - and sometimes even directly if you consider the 2016 terrorist attack in Bishkek - impacts, and is in close proximity to OSCE members, including Kyrgyzstan and Kazakhstan.

\section{The Kurdish Identity}

As argued by Hakan Yavuz, the politicisation of the Kurdish identity cannot be understood prior to nation-state formation. Rather, it is defined by its particular context, i.e. the nature of the state and nationalism in the Middle East, including the failure to include the Kurds into the identity of the state and the utilisation of the Kurdish communities by regional powers. ${ }^{33}$ Following the fall of the Ottoman Empire, the newly established states needed to forge unified identities, whereby any sign of divergence posed a threat to the integrity and harmony of the newly established states. The still mouldable nature of the identity of the state required tough positioning. Nevertheless, Iran, and to a lesser extent Iraq, did recognise their multi-ethnic and multi-cultural character. ${ }^{34}$ Yet, effectively, the identity of the sovereign, i.e. Persian and Arab respectively was the identity to be prioritised. ${ }^{35}$ In Syria and Turkey, ethnic heterogeneity was emphasised alongside equal rights for all. In practice, however, equal rights were only granted to those who renounced their Kurdish identity while taking on the identity of the state. ${ }^{36}$ As argued by Kymlicka with respect to the Turkish case, "the problem is not that Turkey refuses to accept Kurds as Turkish citizens. The problem is precisely its attempt to force Kurds to see themselves as Turks." ${ }^{37}$ This 'attempt' was by no means voluntary, nor painless;

33 M. Hakan Yavuz, "A preamble to the Kurdish question: the politics of Kurdish identity," Journal of Muslim Minority Affairs, 18, no.1 (1998).

34 For Iran, see Vali, "The Kurds," 91; for Iraq, see Denise Natali, "Manufacturing identity and Managing Kurds in Iraq," in Right-sizing the State: the Politics of Moving Borders, ed. O'Leary et al. (Oxford: Oxford University Press, 2003), 253.

35 Vali, The Kurds," 91.

36 For Turkey, see Will Kymlicka, "Misunderstanding Nationalism," in Politics in the Vernacular: Nationalism, Multiculturalism, and Citizenship (Oxford: Oxford University Press, 2001); for Syria, see Maureen Lynch and Perveen Ali, "Buried Alive: Stateless Kurds in Syria," Refugees International (2006).

37 Kymlicka, "Misunderstanding Nationalism". 
it had to be actively forged with the use of arms. ${ }^{38}$ It was, however, unsuccessful, as the policies of exclusion have enforced rather than undermined Kurdish nationalism. ${ }^{39}$ Moreover, Kurdish nationalism has been defined by the repressive features of state nationalism in Iraq, Iran, Syria and Turkey, which has laid the groundwork for an exclusionary form of Kurdish nationalism to arise. ${ }^{40}$

\section{The Uyghur Identity}

Where Chinese nationalism envisions China as a multi-ethnic pluralistic nation, it similarly seeks the creation of a unified identity. While they seek the eradication of ethnicity altogether, they see ethnic unity as a step towards its realisation. Yet, rather than promoting an overarching Chinese identity in which the various ethnic identities can be incorporated, Chinese nationalism introduces a hierarchy of ethnic-religious identities whereby "the Han remain the imagined centre of the nation." ${ }^{41}$ Identifying oneself as 'Chinese' is thereby made to mean being 'Han'. The (implicit) superiority of the Han identity has deemed all other identities, including the Uyghur identity, as threatening to the unity and harmony of the Chinese state. According to the party-state's ideology, the three evils of separatism, terrorism and extremism thwart national unification, pivotal to progress and prosperity. ${ }^{42}$ Consequently, the Uyghurs became an obstacle to Chinese unity resulting from their non-Han identity and perceived separatist desires. As such, they are coined 'un-Chinese'; though Uyghurs as individuals could be Chinese nationals, the Uyghur community as a whole is depicted as a threatening outsider endangering the road towards national unification. The party's desire or end-goal so to say, is the fading away of ethnicity and the fusion of 56 ethnic groups into the common identity. Yet, this is practically thwarted through the creation of internal boundaries, i.e. excluding those who are considered to go against national unification. As argued by David Tobin, "the party-state's exclusion of those who do not understand themselves in this way [as Chinese] only politicise moderate voices that see themselves as Turkic but 'just want peace' ${ }^{33}$ Similarly, officially sanctioned

\footnotetext{
38 Vali, "the Kurds," 85.

39 Vali, The Kurds.

40 Vali, The Kurds, 83-4.

41 David Tobin, "Competing Communities: Ethnic Unity and Ethnic Boundaries on China's North-West Frontier," Inner Asia 23, no.1 (2011): 23.

42 Tobin, Competing Communities," 12.

43 David Tobin, “Competing Communities," 22.
} 
mass influx of Han Chinese into the Uyghur region has prompted a sense of threat and urgency amongst the Uyghurs, as they perceive their identity to be under threat. ${ }^{44}$ As a consequence, the communities are drifting apart. Ethnic unity is not a lived experience; instead Uyghurs fear extinction in a Han-dominated China. And so segregated identities are forged, whereby the Uyghurs are perceived as threatening to national unification, while the Han are considered threatening to the survival of the Uyghur identity. Voila, all the ingredients for a clash. Moreover, the Soviet Union added fuel to the fire by actively supporting the Uyghur uprisings after the Sino-Soviet split. Interestingly, this national, perhaps even local dispute became an international one with the global war on terror and the rise of global jihad. The Chinese support for 'the global war on terror' in the direct aftermath of the 9-11 attacks was contingent upon the US support for their internal Uyghur issue. ${ }^{45}$ This explains to a large extend how the Uyghurs became part of an international agenda. There is a certain similarity with the situation in the Central Asian countries, where political instability and local clashes left all five, but particularly Tajikistan, Southern Kyrgyzstan and Uzbekistan vulnerable to recruiters who skilfully exploit inter-ethnic tensions and feelings of alienation among national minorities. ${ }^{46}$

\section{The Basque Identity}

ETA (Euskadi ta Askatasuna - Basque country and freedom) is a product of the interaction between traditional Basque nationalism on the one hand and Francoism on the other. ${ }^{47}$ While a certain sense of affinity between the Basque 'people' had existed following a common language, culture and customs; Basque nationalism, which is grounded in the idea that the Basque country is occupied by the Spanish state and therefore needs liberation, became a reality

44 Eric Hyer, "China's policy towards Uyghur nationalism," Journal of Muslim Minority Affairs 26, no.1 (2006): 8 o.

45 Human Rights Watch. "Devastating Blows: Religious Repression of Uighurs in Xinjiang", April 11, 2005, https://www.hrw.org/report/2005/04/11/devastating-blows/religious-repres sion-uighurs-xinjiang.

46 B. Ibraev, "Addressing the Daesh Threat in the Context of Central Asia," Norwegian Institute of International Affairs, OSCE Academy, January 2016, pp. 1-24; International Crisis Group, "Syria Calling: Radicalisation in Central Asia," Europe and Central Asia Briefing $N_{72}$, January 2015.

47 Gurutz Jauregui, "National identity and political violence in the Basque country," European Journal of Political Research 14 (1986): 587 . 
under Franco. ${ }^{48}$ Basque nationalism generally and the ETA specifically are best understood in relation and response to the centralised Spanish state-building practices. It flourished, if not radicalised following the installation of the Franco political regime and its persecutory politics. ${ }^{49}$ As such, the ETA is defined by its resistant character. This has been affirmed by the evolution of Basque nationalism in the post-Franco period and the subsequent institutionalisation of autonomy, as in recent times, pluralism is much more accepted in 'Basque nationalist thinking. ${ }^{50}$ Yet, the seeds of tension have been planted whereby the politicisation of Basque nationalism reached a point of no return. A political discourse had been gaining prominence whereby the Basque had to choose between two alternatives, namely the Basque identity and the Spanish identity as if they were incompatible. ${ }^{51}$ This incompatibility is fostered by state-building processes, which are aimed at imposing a certain incompatibility among collective identities through the politicisation of identities. ${ }^{52}$ As such, they forge a discrepancy between being Spanish on the one hand and being of Basque descent on the other. In response, Basque nationalism was presented as irreconcilable with Spanish nationalism. As Alfonso Pérez-Agote concludes after years of extensive research on the topic, "in the Basque case, the present conflict is about the definition of the "we"- between a "we" that is objectified and promulgated by the state and a "we" that emerges from the Basque Country itself. ${ }^{53}$ Both sides internalise the political discourse to the extent that they can no longer see the two identities as part of one reconcilable coin. Once internalised, reversing this process proves extremely difficult.

\section{Why and When Will Identity Formation Turn Violent?}

As we have seen in the above-described cases, state-building processes are exclusionary in nature by favouring one identity (oftentimes, but certainly not always, the majority identity) at the expense of all other identities (oftentimes minority identities) in an attempt to foster unity. Yet where the rise of the nation-state along with the rise of nationalism constitutes a defining feature of

\footnotetext{
48 Jaurgui, "National identity," 587.

49 Alfonso Pérez-Agote, The social roots of Basque Nationalism, trans. C. Watson and W. A. Douglass (Reno, Nevada: University of Nevada Press, 2006): xxvi.

50 Pérez-Agote, The social, xxi.

51 Pérez-Agote, The social, 24.

52 Pérez-Agote, The social, 24.

53 Pérez-Agote, The social, xix.
} 
the post-colonial era in which we live, the policies of in- and exclusion that state-building practices produce have differed per context. As the Kurdish, Uyghur and Basque examples have shown; the degree to which assimilation, suppression and denial are pursued varies. While some states emphasise ethnic singularity, others recognise their multi-ethnic and multi-cultural character. Yet, reality teaches us that in practice, the significance of this recognition is often extremely limited. This is contingent on various factual and non-factual, i.e. perceived, factors, including the composition and size of the various groups within a state, the history and trajectory of state-formation, as well as the extent to which the leadership considers, claims or frames the multi-ethnic character to pose a threat to its very survival. As we have seen, the latter is in itself a product of a complex set of factors and events, all of which will impact the likelihood of reactionary collectives to turn violent. In the process of statebuilding and the politicisation of group identities, some will be left behind. Those who are (or feel) left behind will identify themselves in relation to the in-group and are likely to form a collective that subsequently can be mobilised by brokers of violence to oppose the dominating group and/or the state they represent. Individuals become, as part of the collective, more vulnerable to recruitment and radicalisation, as recruiters exploit feelings of marginalisation and exclusion by offering a place of belonging; a new in-group; a new 'us' or even a new 'nation' so to say. The discourse of injustice develops along national and ethnic lines and is steered towards the opposition of the government.

Several factors associated with drivers of violent extremism stand out when we consider the final step of the theoretical framework, the step from exclusion to radicalisation. According to a major study done by United Nations Development Programme (UNDP) on drivers of violent extremism in Africa "[i]t emerges strongly that the journey to extremism is significantly marked by a fractured relationship between the state and the citizen." 54 While this study was conducted on the African continent, and one could argue it bears relevance merely to contexts in which corruption, human rights abuses and securitisation are prevalent, the very finding that grievances against the government, and particularly against the law enforcement agencies, is associated with recruitment to violent extremism is in itself significant given the very nature of state-building practices. Of the drivers of violent extremism revealed through studies conducted in various parts of the world by UNDP, Mercy Corps, Crisis Group and others, factors associated with government (in)action feature

54 United Nations Development Program, "Journey to Extremism in Africa: Drivers, Incentives and the Tipping Point for Recruitment," 2017, 68 [emphasis added by authors]. 
prominently, including frustration and dissatisfaction with the government for negligence, marginalisation and abuse; a lack of trust in authorities and justice systems; and exposure to state violence against civilians. ${ }^{55}$ Corruption along ethnic lines, heavy-handed police repression, labour market discrimination as well as discrimination in the personnel composition of law enforcement agencies are all examples of (in)action that fuel anger and frustration while politicising ethnic differences. What's more is that one of the few (if not the only) direct encounters between citizens and the (representatives of the) state is in their confrontation with the police. Where these confrontations are marked by police corruption and abuse, this will be projected on the state as such, as citizens will perceive the state as corrupt and abusive. Furthermore, the selffulfilling prophecy of treating minorities as potential terrorists, which leaves them offended, outraged and eventually perhaps more vulnerable to recruitment, is a recurring theme. It has also had quite problematic consequences for the potentially constructive role that the HCNM could play in de-escalating tensions through dialogue, by limiting its mandate to exclude minorities using terrorists' methods. Moreover, government action constitutes the tipping point for 71 percent of the individuals "to shift from generalised radicalisation to a new status of violent extremist ready to perpetrate terrorist acts" according to UNDP. ${ }^{56}$ Where government inaction or negligence as well as repression and corruption feature more prominently in some parts of the world than others, this does not do away with the fact that the way citizens see their respective states' impacts their acceptance towards, and perhaps even willingness to engage in violence. ${ }^{57}$ This is particularly disturbing given that the very basis of this state-citizen relationship is, theoretically speaking, exclusionary in nature, also in many 'democratic' states.

Secondly, an additional factor that features prominently is related to the concept of relative deprivation. Relative deprivation refers to feelings of deprivation in relation to others. There might be a general lack of the rule of law, widespread corruption and limited economic opportunities, yet anger and frustration arises when one feels that he or she suffers the consequences, -often as part of a collective- whereas others may not (or not as much). Consequently,

55 United Nations Development Program, "Journey to,"; International Crisis Group, "Syria Calling: Radicalisation in Central Asia," Europe and Central Asia Briefing N72, January 2015; Mercy Corps, "How to Reduce Violent Extremism: Putting Peacebuilding and Development first," February 2018.

56 United Nations Development Program, "Journey to," 73.

57 Huma Haider, "State-Society Relations and Citizenship in Situations of Conflict and Fragility," The Governance and Social Development Resource Centre, December 2011. 
it is not so much the perceived lack of opportunities, but rather the perceived lack of equal opportunities between members of different groups or identities that is put forward as a condition considered conducive to radicalisation and recruitment into violent environments. Related to the concept of relative deprivation is the prominence of unmet expectations. According to research conducted by Mercy Corps "especially for youth, conceptions of gender roles, respect, and status factored significantly into decisions about whether or not to join an armed group." 58

Thirdly, all of these studies highlight the frequently sociable nature of radicalisation and recruitment processes. Radicalisation is not an individual process. It is a collective process. According to UNDP, after government action, the second most likely final motivation to join violent extremist groups relates to 'joining with friends'.59 Furthermore, those that joined violent extremist groups on their own constitute only 17 percent whereas friends and family members feature prominently in facilitating recruitment processes.

If we take these three findings together; the fractured state-citizen relation, the identity politics that is an inherent part of state-building processes, the prominence of (collective) relative deprivation, and lastly the highly sociable nature of radicalisation, the first steps of the theoretical framework laid out above become highly worrisome as the final step from exclusion to radicalisation becomes logical and apparent due to the prominence of identity politics and collective exclusion in both processes. Radicalisation is often misunderstood because the underlying processes are analysed as if they are solely individual trajectories. Radicalisation is as much about 'the collective'; the quest for belonging following exclusion by the state; the marginalised community against the dominant elite. As put forward by the wANA Institute, "the weak national identities in the region [the Middle East] were easily discarded in favour of a newly crafted powerful identity." ${ }^{\prime 60}$ State-building processes taken together with smart recruitment techniques feed the antagonism underlying political tensions that lead to violence in its final stages. Where one door closes, another one opens. Newly crafted identities build on, and cater to years of tension and marginalisation while the narrowly defined national identities offer no resilience to the exploitation of these sentiments by violent groups. As we have seen, the results can be devastating.

58 Mercy Corps, "How to".

59 United Nations Development Program, "Journey to," 74.

6o West Asia-North Africa Institute, "Post-Daesh and still desperate: The ongoing Drivers of Violent Extremism in Jordan, Tunisia, and Lebanon," March 2018, 8. 


\section{Conclusion}

Notwithstanding the complexities and local variation, nation-state building feeds specifically into the radicalisation of (minority) communities following its essentially exclusionary features. As such, violent extremism and radicalisation leading to terrorism is perhaps best understood as a social movement in, as the term would suggest, its most radical form; a collective response to internal border construction and elite domination. The majority of studies into the phenomenon of radicalisation largely failed to see this pattern due to the focus on the individual. The individual trajectories have puzzled researchers as they were blinded to the social component. There are many pathways into radicalisation. Every tree is different. Hence the fact that researchers claim that there are many pathways into violent extremism. Yet, the birds-eye view may prove to be helpful in discovering the forest. Many questions need answering, including the role of brokers of violence, the emergence of an effective or attractive leader as well as the role that ideology and religion play. These factors are certainly interconnected and deserve our full attention. Yet, as we have tried to show, there is a need for awareness building concerning state-building practices leaving significant parts of populations at its margins. It provokes opposition to the monopoly on the use of violence claimed by states. This implies the revisiting of state-building project(s), the redefinition of national unity and perhaps most importantly, the search for inclusionary policies. Policies directed towards genuine redefinition of the 'us' and the accommodation of differences. It is exactly through the promotion, facilitation and execution of inclusive policies that the OSCE can make an important contribution due to its strong local presence as well as its wide reach through diverse membership. While acknowledging the political sensitivity of the issue, it is and remains the main role of the OSCE, and more specifically the HCNM, to identify and address tensions involving national minorities. Perhaps even as a result of the sensitivity and complexity of the issue, the OSCE remains one of the few actors that is skilled and mandated to work together with governments in fostering social cohesion. The added value lies in its dedication, tools and experience, but perhaps even more importantly, its willingness to learn, and make use of new insights and research. We are therefore confident that the structural problem that we have aimed to lay bare will receive the wholehearted attention of the HCNM. After all, one cannot deny that the notion of the state is crumbling. Acknowledging the underlying reasons for demise is the first step towards its reinvention or (re)construction and durable solutions. Not simply with the intent to preserve sovereignty as a basis for international politics, but rather because we have to be serious about responding to the issues at hand. It is now up to the OSCE. And we are pleased that it is. 